\title{
KAJIAN PERUBAHAN LAHAN MENJADI PERMUKIMAN DAN KARAKTER- ISTIKNYA DI DAERAH ALIRAN SUNGAI (DAS) CILIWUNG BAGIAN HILIR
}

The Study of Land Conversion Into Settlements and Its Characteristics in The Downstream of Ciliwung Watershed.

\section{Nindy Aslinda}

Divisi Perencanaan Lanskap, PT. Metropolitan Land,

Cileungsi

Email : nindyaslin-

da@yahoo.co.id

\section{Syartinilia}

Staf Pengajar Departemen Arsitektur Lanskap, Fakultas Pertanian IPB

\begin{abstract}
Ciliwung Watershed is one of watershed that across the Jakarta capital region. Ciliwung Watershed is categorized as super-priority watershed in Indonesia. The study was conducted in downstream of Ciliwung Watershed in Jakarta. This study aimed to analyze land cover changes from greenery open space to build up area in period of 1993-2013 and to analyze the distribution of settlement and its characteristics in the downstream of Ciliwung Watershed. LANDSAT images data of 1993 and 2013 were classified using supervised classification method to produce land cover map. The results of the map are analyzed spatially and descriptively to determine the changes. The greenery open space have changed into built up area about $70.07 \%$ during 20 years in the downstream of Ciliwung watershed. While, the settlement is dominated by the unplanned settlement (87.23\%). Meanwhile, the settlements were dominated by unplanned settlements $(87.23 \%)$ which characterized by linier settlement patterns, very lage size of settlement, low to medium building density, and good condition of insfrastructure. Five recommendations have provided for landscape managing of settlement in downstream of Ciliwung Watershed..
\end{abstract}

Keyword: Ciliwung Watershed, Characteristics of settlement, Greenery Open Space, Supervised classification

\section{PENDAHULUAN}

\section{Latar Belakang}

DAS merupakan satu ekosistem yang terdiri dari wilayah hulu yang berfungsi sebagai wilayah konservasi air, wilayah tengah yang berfungsi sebagai wilayah pemanfaatan air, dan wilayah hilir yang berfungsi sebagai wilayah pengaturan air (drainase). DAS Ciliwung memiliki panjang $117 \mathrm{~km} 2$ dan meliputi areal seluas $370.80 \mathrm{~km} 2$. Berdasarkan Surat Keputusan Menteri Kehutanan Nomor 328 tahun 2009 tentang Penetapan Daerah Aliran Sungai (DAS) Prioritas dalam Rangka Rencana Pembangunan Jangka Menengah (RPJM) tahun 2010-2014, DAS Ciliwung merupakan salah satu DAS yang berstatus sebagai DAS Super Prioritas, hal ini dikarenakan wilayah hilir DAS Ciliwung meliputi wilayah Ibukota Jakarta yang berstatus sebagai kawasan strategis nasional di Indonesia.

DAS Ciliwung memiliki permasalahan berupa tingginya laju perubahan penutupan lahan dari Ruang Terbuka Hijau (RTH) menjadi ruang terbangun di wilayah tersebut. Pada Tahun 1990 penutupan lahan terbesar di wilayah tersebut berupa ruang terbangun $(52.76 \%)$, Ruang Terbuka Hijau (RTH) (33.75\%), dan badan air $(13.49 \%)$. Pada Tahun 2000 luas RTH menurun menjadi $27.07 \%$, sedangkan luas ruang terbangun meningkat menjadi $61.05 \%$. Adapun perubahan menjadi ruang terbangun yang paling banyak terjadi di wilayah hilir yaitu mencapai $80.00 \%$ (Melati et al 2002). DAS Ciliwung sebagai bagian dari Ibukota Jakarta mengalami perkembangan permukiman yang sangat pesat. Pada tahun 1990 luas permukiman sebesar $36.12 \%$ dan mengalami peningkatan menjadi sebesar $37.22 \%$ pada tahun 2000. Adapun luas kawasan permukiman terbesar terdapat di wilayah hilir yaitu mencapai $62.00 \%$ (Melati et al 2002). Perkembangan permukiman, khususnya di DAS Ciliwung hilir berdampak terhadap keanekaragaman karakteristik permukiman di wilayah tersebut yaitu baik pemukiman yang terencana yaitu permukiman yang dibangun oleh pengembang (developer), dan permukiman tidak terencana, yaitu permukiman yang dibangun sendiri oleh masyarakat. Oleh karena itu perlu adanya analisis mengenai karakteristik permukiman di DAS Ciliwung Hilir guna menghasilkan output berupa rekomendasi pengelolaan permukiman yang sesuai di wilayah tersebut.

Tujuan dari penelitian ini adalah:

1. menganalisis perubahan penutupan lahan dari Ruang Terbuka Hijau (RTH) menjadi ruang terbangun dalam 20 tahun (1993-2013) dan distribusinya di DAS Ciliwung Hilir,

2. menganalisis distribusi permukiman terencana dan tidak terencana,

3. menganalisis karakteristik permukiman di DAS Ciliwung Hilir.

\section{METODE}

Waktu dan Lokasi Penelitian 
Penelitian ini dilakukan dari Bulan Maret 2013 sampai November 2014. Kegiatan penelitian ini meliputi tahap inventarisasi (pengumpulan data), analisis spasial dan analisis karakteristik permukiman serta sintesis berupa penyusunan rekomendasi pengelolaan lanskap permukiman. Lokasi penelitian terletak di DAS Ciliwung Hilir, Jakarta (Gambar 1).

\section{Alat dan Bahan Penelitian}

Alat yang digunakan dalam penelitian ini adalah Global Positioning System (GPS), kamera digital, alat tulis dan komputer dalam pengolahan data menggunakan Geographic Information System (GIS) seperti ERDAS Imagine 9.1, Arc GIS 9.3 Version dan Global Mapper. Jenis data, sumber dan kegunaannya dalam penelitian ini dapat dilihat pada Tabel 1.

Tabel 1 Jenis, bentuk, sumber data dan kegunaan

\begin{tabular}{|c|c|c|c|}
\hline Jenis Data & $\begin{array}{l}\text { Bentuk Da- } \\
\text { ta }\end{array}$ & Sumber Data & Kegunaan \\
\hline $\begin{array}{l}\text { Citra Landsat } 7 \\
\text { TM (04/12/1993) }\end{array}$ & $\begin{array}{l}\text { Raster, } \\
\text { resolusi } \\
30 \times 30 \mathrm{~m}\end{array}$ & LAPAN & $\begin{array}{l}\text { Analisis pe- } \\
\text { nutupan la- } \\
\text { han tahun } \\
1993\end{array}$ \\
\hline $\begin{array}{l}\text { Citra Landsat } 8 \\
\text { TM }(06 / 04 / 2013)\end{array}$ & $\begin{array}{l}\text { Raster, } \\
\text { resolusi } \\
30 \times 30 \mathrm{~m}\end{array}$ & LAPAN & $\begin{array}{l}\text { Analisis pe- } \\
\text { nutupan la- } \\
\text { han tahun } \\
2013\end{array}$ \\
\hline Data RTRW & Deskriptif & $\begin{array}{l}\text { BAPPEDA } \\
\text { Jakarta }\end{array}$ & $\begin{array}{l}\text { Analisis pe- } \\
\text { rubahan pe- } \\
\text { nutupan la- } \\
\text { han }\end{array}$ \\
\hline Data RDTR & Deskriptif & $\begin{array}{l}\text { Dinas Tata } \\
\text { Ruang Jakarta }\end{array}$ & $\begin{array}{l}\text { Analisis pe- } \\
\text { rubahan pe- } \\
\text { nutupan la- } \\
\text { han }\end{array}$ \\
\hline Peta Batas DAS & Vektor & $\begin{array}{l}\text { BPDAS Cili- } \\
\text { wung }\end{array}$ & $\begin{array}{l}\text { Penentuan } \\
\text { wilayah } \\
\text { penelitian } \\
\text { (DAS Cili- } \\
\text { wung Hilir) }\end{array}$ \\
\hline $\begin{array}{l}\text { Peta Administrasi } \\
\text { Kecamatan dan } \\
\text { Desa }\end{array}$ & Vektor & PPLH IPB & $\begin{array}{l}\text { Penentuan } \\
\text { sampel } \\
\text { penelitian (3 } \\
\text { Kecamatan) }\end{array}$ \\
\hline $\begin{array}{l}\text { Data } \\
\text { Kependudukan }\end{array}$ & Deskriptif & $\begin{array}{l}\text { Kecamatan } \\
\text { dalam Angka, } \\
\text { Laporan Ta- } \\
\text { hunan Ke- } \\
\text { lurahan, Sur- } \\
\text { vey lapang }\end{array}$ & $\begin{array}{l}\text { Analisis uku- } \\
\text { ran } \\
\text { kepadatan } \\
\text { Permukiman, }\end{array}$ \\
\hline
\end{tabular}

Keterangan :
1. LAPAN : Lembaga Antariksa dan Penerbangan Nasional

2. PPLH : Pusat Penelitian Lingkungan Hidup

3. BPDAS : Balai Penelitian Daerah Aliran Sungai

4. RTRW :Rencana Tata Ruang dan Wilyah

5. RDTR : Rencana Detail Tata Ruang

\section{Metode}

Penelitian ini dilakukan dengan beberapa tahapan yaitu inventarisasi, analisis penutupan lahan, perubahan penutupan lahan, dan karakteristik permukiman, serta pembuatan rekomendasi pengelolaan lanskap permukiman di DAS Ciliwung Hilir.

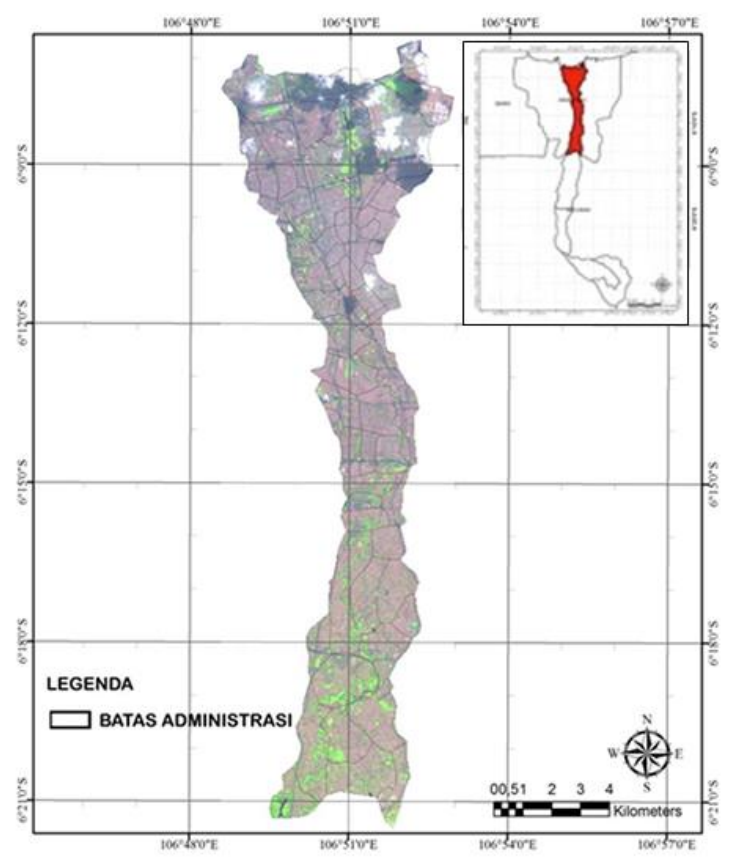

Gambar 1. Lokasi penelitian (DAS Ciliwung Hilir)

(Sumber: Landsat 8 Tanggal 6 April 2013)

\section{Inventarisasi}

Pada tahap inventarisasi dilakukan kegiatan pengumpulan data dan survai lapang. Data yang diperlukan berupa data spasial (raster dan vektor) dan data non spasial (deskriptif). Pada tahap survey lapang dilakukan pengumpulan data non spasial berupa pengamatan langsung di lokasi penelitian, wawancara dengan pihak terkait dan dokumentasi lapang, serta studi pustaka yang terkait dengan tujuan penelitian.

\section{Klasifikasi Penutupan Lahan}

Peta penutupan lahan dibuat dari citra satelit Landsat 7 tanggal 4 Desember 1993 dan citra satelit Landsat 8 tanggal 6 April 2013. Peta penutupan lahan dihasilkan dengan menggunakan klasifikasi terbimbing pada 
software ERDAS Imagine 9.1. Kriteria pengelompokan kelas diterapkan berdasarkan penciri kelas (class signature) yang diperoleh melalui pembuatan training area (area contoh) berdasarkan hasil survey lapang (Aryanti 2011). Training area yang digunakan dalam penelitian yaitu ruang terbuka hijau (RTH), ruang terbangun, dan badan air. Pendugaan akurasi dilakukan terhadap hasil penutupan lahan yang diperoleh dengan menggunakan accuracy assesment dari software ERDAS Imagine 9.1 dengan tingkat akurasi minimal $75.00 \%$ (Syartinilia 2004).

\section{Analisis Perubahan Penutupan Lahan}

Metode yang digunakan pada proses ini adalah Post Classification Comparison yang bertujuan untuk mengetahui perubahan penutupan lahan di lokasi penelitian. Metode ini menggunakan fungsi perkalian antara nilai kelas penutupan lahan tahun 1993 dengan tahun 2013 yang telah di-recode terlebih dahulu. Proses tersebut menghasilkan image baru yang mengandung informasi berupa penutupan lahan yang berubah ataupun yang tidak mengalami perubahan dalam kurun waktu tersebut. Hasil perkalian matriks tersebut menghasilkan kelas penutupan lahan dengan nilai baru. Nilai tersebut menggambarkan perubahan masingmasing kelas dalam periode 1993-2013. Hasil akhir yang didapatkan dari analisis tersebut berupa peta perubahan penutupan lahan dari RTH menjadi ruang terbangun di DAS Ciliwung hilir.

\section{Analisis Distribusi Permukiman}

Pada tahap ini dilakukan deteksi distribusi permukiman pada 3 kecamatan terpilih. Analisis spasial dilakukan dengan cara deliniasi kawasan permukiman dengan menggunakan software Google Earth berdasarkan teratur atau tidaknya pola permukiman. Tahap selanjutnya yaitu menginput data hasil deliniasi kawasan permukiman pada software ArcGIS 9.3 sehingga diperoleh peta distribusi permukiman.

\section{Analisis Karakteristik Permukiman}

Metode yang digunakan dalam analisis karakteristik permukiman terdiri dari 4 tahapan, yaitu:

1. penentuan sampel, yaitu menentukan jumlah sampel permukiman masing-masing 1 permukiman terencana dan 1 permukiman tidak terencana di 3 RW pada 3 kecamatan terpilih,

2. analisis pola permukiman, yaitu interpretasi pola permukiman berdasarkan hasil studi pustaka dengan cara deliniasi kawasan permukiman dengan menggunakan software Google Earth untuk selanjutnya dilakukan georeferencing
3. analisis kepadatan permukiman, yaitu membandingkan kepadatan bangunan dalam suatu blok permukiman. Menurut Martono et al. (2013), kepadatan permukiman dirumuskan sebagai berikut :

\section{Kepadatan Permukiman $=$}

$\sum$ Luas Seluruh Atap

$\overline{\sum \text { Luas Seluruh Blok dalam Satu Unit Permukinan }}$

Adapun kriteria kepadatan permukiman menurut Dinas pekerjaan umum yaitu rendah $(\leq 40.00 \%)$, sedang $(40-60 \%)$, dan tinggi $(\geq 60.00 \%)$.

4. analisis infrastruktur permukiman dengan menggunakan metode skoring, yaitu pemberian skor pada masing-masing aspek untuk selanjutnya dilakukan penjumlahan guna mengetahui kualitas infrastruktur permukiman di lokasi terpilih. Adapun skor dilakukan terhadap aspek infrastruktur permukiman yang telah ditetapkan oleh Dinas Pekerjaan Umum meliputi jalan, saluran drainase, air bersih dan pembuangan sampah dapat dilihat pada (Tabel 2). Pada tahap ini dilakukan penilaian kondisi infrastruktur oleh ketua RT/RW pada lokasi permukiman terpilih, berdasarkan kriteria skor yang telah ditetapkan Dinas PU. Adapun total dari hasil penilaian tersebut dihitung menggunakan metode skoring yang dikemukakan oleh Selamet (1983) dalam Alvino (2014).

$$
\begin{gathered}
\text { Interval Kelas (IK) }= \\
\frac{\text { Skor Maksimum (Sma) - Skor Minimum (Smi) }}{\text { Jumlah Kategori }}
\end{gathered}
$$

Keterangan :

Tinggi $=\mathrm{SMi}+2 \mathrm{IK}+1$ sampai SMa

Sedang $=\mathrm{SMi}+\mathrm{IK}+1$ sampai $(\mathrm{SMi}+2 \mathrm{IK})$

Rendah $=$ SMi sampai Smi+ IK

Penyusunan Rekomendasi

Tahap akhir berupa penyusunan rekomendasi berdasarkan hasil analisis guna menghasilkan rekomendasi pengelolaan permukiman yang sesuai pada lokasi peneliti

\section{HASIL DAN PEMBAHASAN}

\section{Penutupan Lahan}

Berdasarkan peta penutupan lahan DAS Ciliwung Hilir pada tahun 1993 (Gambar 2) 
diketahui bahwa kecamatan dengan luas ruang terbangun terbesar yaitu Kecamatan Tebet. Kecamatan dengan luas RTH terbesar yaitu Kecamatan Pasar Rebo (795 ha), sementara itu Kecamatan Tebet dengan ruang terbangun terbesar yaitu sebesar 702.26 ha (14.38\%) (Tabel 3). Hal ini disebabkan peruntukkan Kecamatan Tebet sebagai kawasan permukiman di wilayah Jakarta Selatan menurut RTRW DKI Jakarta tahun 1990-2010, sehingga berdampak pada semakin meningkatnya ruang terbangun, khususnya permukiman di wilayah tersebut.

Berdasarkan peta penutupan lahan DAS Ciliwung Hilir pada tahun 2013 (Gambar 4) diketahui bahwa kecamatan dengan luas ruang terbangun terbesar yaitu Kecamatan Pasar Rebo. Kecamatan dengan luas RTH terbesar yaitu Kecamatan Jagakarsa (239.6 ha) dan Kecamatan Pasar Rebo dengan ruang terbangun terbesar yaitu sebesar 950.53 ha (Tabel 3). Hal ini disebabkan Kecamatan Pasar Rebo juga diperuntukkan sebagai wilayah pengembangan kawasan perindustrian di wilayah Jakarta Timur menurut RTRW DKI Jakarta tahun 20102030. Tingginya aktivitas industri mendorong pertumbuhan penduduk, sehingga berdampak pada semakin meningkatnya ruang terbangun di wilayah tersebut.

Tabel 2. Kriteria penilaian infrastruktur permukiman

\begin{tabular}{|c|c|c|c|}
\hline \multirow{2}{*}{ Aspek } & \multicolumn{3}{|c|}{ Skor } \\
\hline & 1 (Rendah) & 2 (Sedang) & 3 (Tinggi) \\
\hline Jalan & $\begin{array}{l}\text { Kerusakan > } \\
70.00 \%\end{array}$ & $\begin{array}{l}\text { Kerusakan } \\
50.00-70.00 \%\end{array}$ & $\begin{array}{l}\text { Kerusakan < } \\
50.00 \%\end{array}$ \\
\hline $\begin{array}{l}\text { Saluran } \\
\text { drainase }\end{array}$ & $\begin{array}{l}\text { Ketinggian } \\
>50.00 \%\end{array}$ & $\begin{array}{l}\text { Ketinggian } \\
25.00-50.00 \%\end{array}$ & $\begin{array}{l}\text { Ketinggian } \\
<25.00 \%\end{array}$ \\
\hline $\begin{array}{l}\text { Air } \\
\text { Bersih }\end{array}$ & $\begin{array}{l}\text { Pelayanan } \\
<30.00 \%\end{array}$ & $\begin{array}{l}\text { Pelayanan } \\
30.00-60.00 \%\end{array}$ & $\begin{array}{l}\text { Pelayanan } \\
>60.00 \%\end{array}$ \\
\hline $\begin{array}{l}\text { Saluran } \\
\text { drainase }\end{array}$ & $\begin{array}{l}\text { Pelayanan } \\
<50.00 \%\end{array}$ & $\begin{array}{l}\text { Pelayanan } \\
50.00-70.00 \%\end{array}$ & $\begin{array}{l}\text { Pelayanan } \\
>70.00 \%\end{array}$ \\
\hline
\end{tabular}

\section{Sumber :Dinas Pekerjaan Umum}

\section{Perubahan Penutupan Lahan}

Dalam kurun waktu 1993-2013 terdapat lahan yang mengalami perubahan dan ada juga yang tetap atau tidak mengalami perubahan (Gambar 5). Jenis penutupan lahan yang mengalami perubahan terbesar berupa RTH menjadi ruang terbangun sebesar 1780.11 ha $(70.07 \%)$. Dalam periode 1993-2013 terjadi pernambahan ruang terbangun sebesar 1633 ha $(29.5 \%)$ dan penurunan RTH sebesar 1705.3 ha (59.5\%)

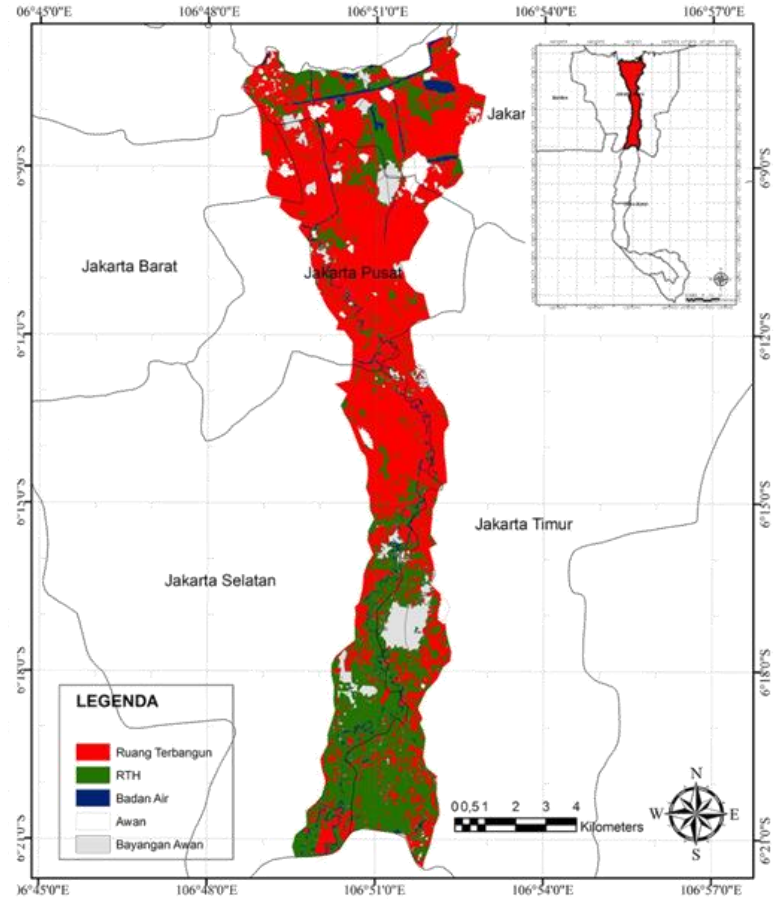

Gambar 3. Peta penutupan lahan di DAS Ciliwung Hilir Tahun 1993

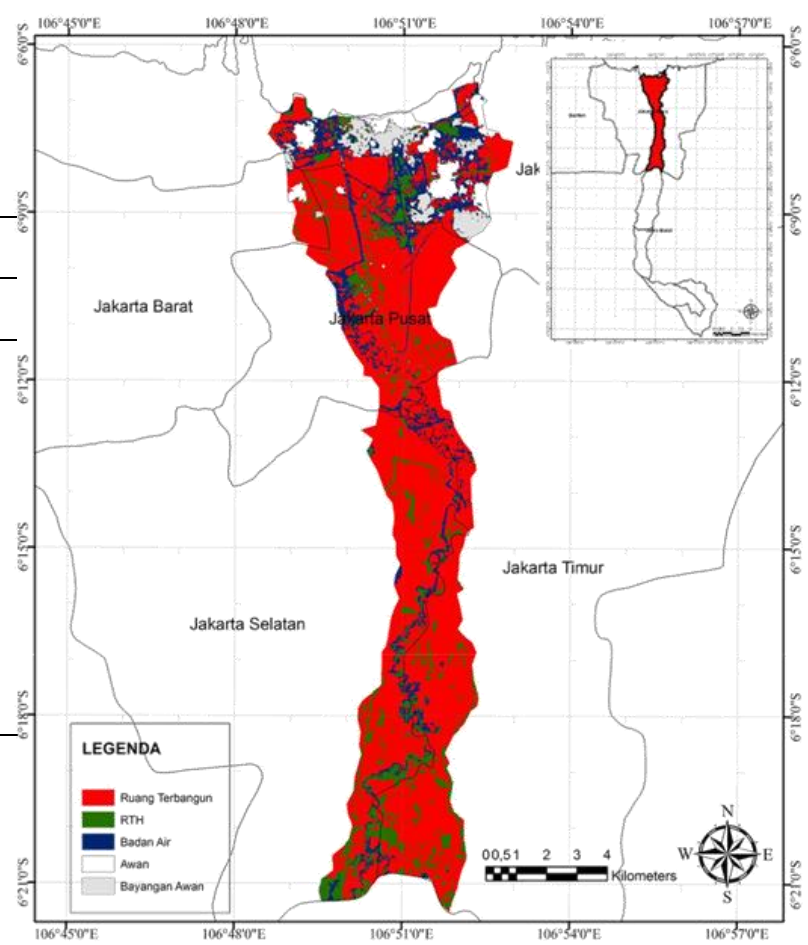

Gambar 4. Peta penutupan lahan di DAS

Ciliwung Hilir Tahun 2013

(Tabel 3). Kecamatan Pasar Rebo, Jagakarsa dan Pasar Minggu merupakan 3 kecamatan dengan perubahan RTH ke ruang terbangun yang 
paling tinggi. Jika dilihat dari kelurahannya yang mengalami konversi lahan ke ruang terbangun yang besar terjadi di Kelurahan Pekayon, Kelurahan Tanjung Barat, dan Kelurahan Pejaten Timur. Hal ini terutama disebabkan oleh meningkatnya jumlah penduduk di ketiga kecamatan tersebut yang menyebabkan kebutuhan akan permukiman juga meningkat. Oleh karena itu tingkat kepadatan penduduk di ketiga wilayah tersebut perlu diperhatikan karena akan beresiko pada terganggunya fungsi ekologis ketiga wilayah tersebut sebagai daerah aliran sungai.

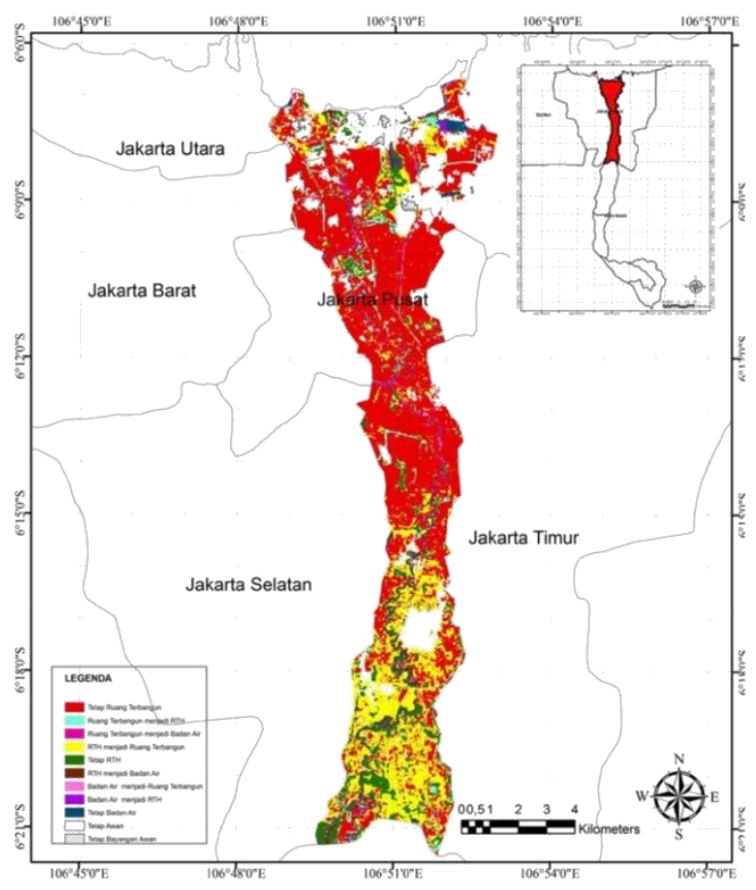

Gambar 5. Peta penutupan lahan yang tetap

dan mengalami perubahan di DAS Ciliwung Hilir periode 1993-2013

\section{Distribusi Pemukiman}

Berdasarkan hasil analisis perubahan penutupan lahan dari RTH menjadi ruang terbangun, diperoleh 3 wilayah yang paling banyak mengalami perubahan terutama menjadi kawasan permukiman (Kelurahan Pekayon, Tanjung Barat, dan Pejaten Timur). Distribusi pemukiman di ketiga wilayah tersebut didominasi oleh permukiman tidak terencana sebesar 236.52 ha $(87.23 \%)$ dan permukiman terencana sebesar 30.96 ha (12.77\%) (Gambar 6). Berdasarkan hasil analisis perubahan penutupan lahan, diperoleh sampel permukiman yaitu permukiman tidak terencana yang berlokasi di RW 02 (Kelurahan Pekayon), RW 01 (Kelurahan Tanjung Barat), dan RW 05
(Kelurahan Pejaten Timur). Sedangkan pada permukiman terencana diperoleh sampel yaitu Komplek Tanjung Mas Estate (Kelurahan Tanjung Barat) dan Komplek Batu Permata (Kelurahan Pejaten Timur).

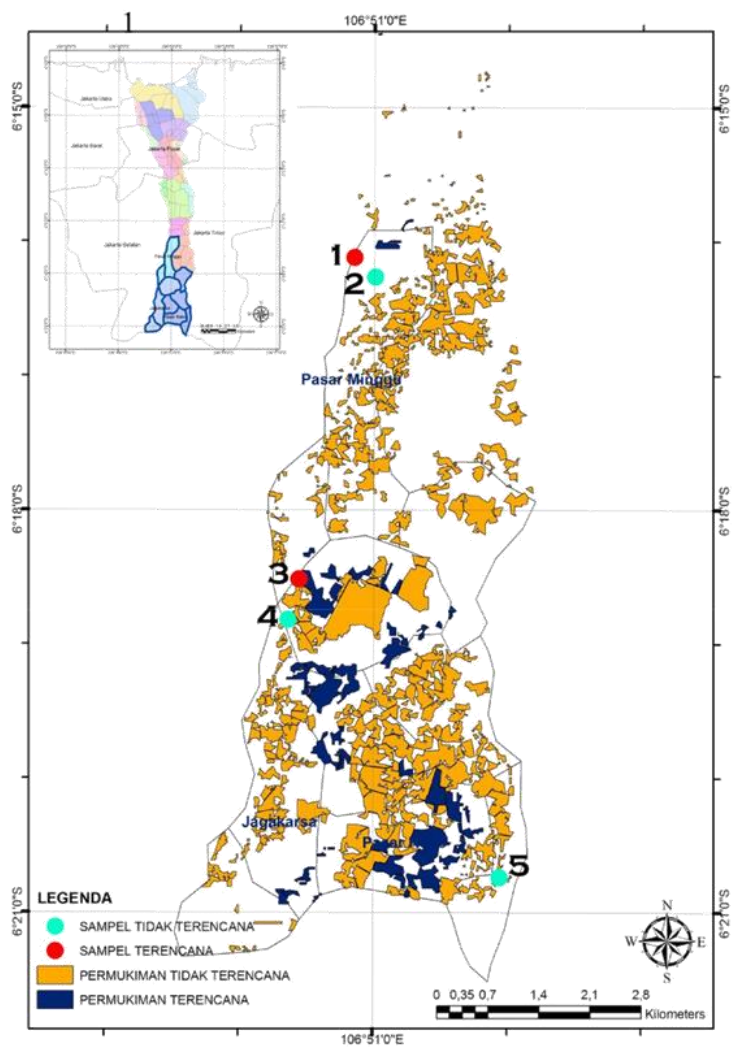

Gambar 6. Distribusi permukiman terencana dan tidak terencana

\section{Karakteristik Permukiman Tidak Terencana}

\section{Pola permukiman}

Berdasarkan hasil analisis pola permukiman dengan menggunakan software Google Earth diketahui bahwa di ketiga lokasi yaitu pada RW 02 (Kelurahan Pekayon), RW 01 (Kelurahan Tanjung Barat) dan RW 05 (Kelurahan Pejaten Timur) memiliki pola permukiman yang linier (memanjang). Bangunan rumah pada umumnya berorientasi pada jalan dan sebagian besar bangunan rumah merupakan bangunan permanen. Pola permukiman memanjang pada jalan terutama dipengaruhi oleh jaringan jalan yang telah ada. Hal ini terkait dengan kemudahan akses yang diperoleh jika membangun permukiman di sepanjang jalan tergolong ke dalam permukiman berukuran sangat besar yaitu sebesar 8689 jiwa. Pada RW 05 (Kelurahan Pejaten Timur) tergolong ke dalam permukiman berukuran sangat yaitu sebesar 5480 jiwa. 
Tabel 3. Perubahan penutupan lahan berdasarkan kecamatan tahun 1993-2013

\begin{tabular}{|c|c|c|c|c|c|c|}
\hline \multirow{2}{*}{ Kecamatan } & \multicolumn{2}{|c|}{$\begin{array}{c}\text { Ruang Terbangun } \\
\text { (ha) }\end{array}$} & \multirow{2}{*}{$\begin{array}{c}\text { Perubahan Ruang } \\
\text { Terbangun (ha) }\end{array}$} & \multicolumn{2}{|c|}{$\begin{array}{c}\text { Ruang Terbuka Hijau } \\
\text { (ha) }\end{array}$} & \multirow{2}{*}{$\begin{array}{c}\text { Perubahan } \\
\text { RTH (ha) }\end{array}$} \\
\hline & 1993 & 2013 & & 1993 & 2013 & \\
\hline Cempaka Putih & 18.6 & 17.0 & -1.6 & 1.4 & 3.4 & 1.9 \\
\hline Gambir & 103.5 & 125.2 & 21.7 & 14.8 & 7.4 & -7.4 \\
\hline Johar Baru & 162.8 & 182.6 & 19.8 & 10.4 & 11.8 & 1.4 \\
\hline Kemayoran & 411.4 & 476.4 & 65.0 & 15.8 & 47.7 & 32.0 \\
\hline Menteng & 345.6 & 371.3 & 25.7 & 41.6 & 15.0 & -26.6 \\
\hline Sawah Besar & 537.2 & 563.6 & 26.4 & 129.1 & 129.3 & 0.2 \\
\hline Senen & 396.8 & 382.2 & -14.6 & 27.2 & 45.4 & 18.2 \\
\hline Pademangan & 542.4 & 582.0 & 39.6 & 324.1 & 123.5 & -200.6 \\
\hline Tanjung Priok & 643.0 & 352.9 & -290.1 & 182.2 & 55.8 & -126.4 \\
\hline Tamansari & 198.9 & 167.4 & -31.5 & 6.9 & 21.8 & 14.9 \\
\hline Jatinegara & 179.3 & 189.3 & 10.0 & 13.6 & 1.9 & -11.7 \\
\hline Kramat Jati & 264.2 & 669.8 & 405.6 & 238.9 & 69.4 & -169.5 \\
\hline Matraman & 102.5 & 135.6 & 33.1 & 12.1 & 1.1 & -11.0 \\
\hline Pasar Rebo & 339.6 & 950.5 & 611.0 & 795.0 & 205.6 & -589.4 \\
\hline Jagakarsa & 167.2 & 529.6 & 362.5 & 565.4 & 239.6 & -325.8 \\
\hline Pancoran & 159.7 & 243.8 & 84.1 & 100.5 & 26.4 & -74.1 \\
\hline Pasar Minggu & 163.2 & 390.1 & 226.9 & 292.2 & 86.7 & -205.5 \\
\hline Setiabudi & 97.8 & 108.6 & 10.9 & 15.1 & 2.9 & -12.2 \\
\hline Tebet & 702.3 & 730.9 & 28.6 & 78.7 & 65.1 & -13.6 \\
\hline Total & 5535.9 & 7168.9 & 1633.0 & 2864.9 & 1159.6 & -1705.3 \\
\hline
\end{tabular}

\section{Ukuran permukiman}

Berdasarkan hasil analisis data kependudukan diketahui bahwa pada RW 02 (Kelurahan Pekayon) tergolong ke dalam permukiman berukuran sangat besar yaitu sebesar 6456 jiwa. Pada RW 01 (Kelurahan Tanjung Barat) Hal ini disebabkan oleh pertumbuhan penduduk di wilayah tersebut akibat lokasi permukiman yang berada di wilayah semi perkotaan. Hal ini menyebabkan harga tanah di wilayah tersebut lebih murah dan berdampak pada banyaknya masyarakat yang berdomisili di wilayah tersebut.

\section{Kepadatan permukiman}

Berdasarkan hasil analisis kepadatan permukiman diketahui bahwa pada RW 02 
(Kelurahan Pekayon) memiliki kepadatan sebesar $51.65 \%$ dan tergolong ke dalam kepadatan sedang. Pada RW 01 (Kelurahan Tanjung Barat) memiliki kepadatan sebesar $39.53 \%$ dan tergolong ke dalam kepadatan rendah. Pada RW 05 (Kelurahan Pejaten Timur) memiliki kepadatan sebesar $49.98 \%$ dan tergolong ke dalam kepadatan sedang. Hal ini disebabkan peruntukkan kawasan ini yang termasuk ke dalam kawasan permukiman dengan Koefisien Dasar Bangunan (KDB) sedang-tinggi menurut RDTR Kecamatan Pasar Rebo, sehingga menyebabkan tingkat kepadatan permukiman di kawasan ini tergolong sedang. Pada RW 01 (Kelurahan Tanjung Barat) tergolong ke dalam permukiman kepadatan rendah. Hal ini disebabkan peruntukkan kawasan ini yang termasuk ke dalam kawasan permukiman dengan KDB sedang-tinggi menurut RDTR Kecamatan Jagakarsa, sehingga menyebabkan tingkat kepadatan permukiman di kawasan ini tergolong rendah. Pada RW 05 (Kelurahan Pejaten Timur) tergolong ke dalam permukiman kepadatan sedang. Hal ini disebabkan peruntukkan kawasan ini yang termasuk ke dalam kawasan permukiman dengan KDB sedang-tinggi menurut RDTR Kecamatan Pasar Minggu, sehingga menyebabkan tingkat kepadatan permukiman di kawasan ini relatif sedang.

\section{Infrastruktur permukiman}

Berdasarkan hasil analisis diketahui bahwa kondisi infrastruktur di ketiga lokasi terpilih tergolong baik. Hal ini dapat dilihat berdasarkan nilai total seluruh aspek (Tabel 4).

Tabel 4. Penilaian infrastruktur permukiman pada permukiman tidak terencana

\begin{tabular}{lccccccc}
\hline \multirow{2}{*}{ Sampel pemukiman } & \multicolumn{5}{c}{ Skor Aspek } & \\
\cline { 2 - 6 } & Jalan & Drainase & Air bersih & Sampah & Total & Keterangan \\
\hline RW02 & Pekayon & 3 & 2 & 3 & 3 & 11 & Tinggi \\
RW 01 Tanjung Barat & 3 & 2 & 3 & 3 & 11 & Tinggi \\
RW05 & $\begin{array}{l}\text { Pejaten Ti- } \\
\text { mur }\end{array}$ & 3 & 2 & 3 & 3 & 11 & Tinggi \\
\hline
\end{tabular}

Keterangan: Nilai total 4-7 = Rendah, 8-10= Sedang, 11-12= Tinggi

(Sudah dijelaskan pada metode)

\subsection{Jalan}

Kondisi jalan pada ketiga lokasi terpilih yaitu RW 02 (Kelurahan Pekayon), RW 01 (Kelurahan Tanjung Barat) dan RW 05 (Kelurahan Pejaten Timur), tergolong ke dalam kondisi yang baik (Gambar 13). Hal ini berdasarkan hasil penilaian 3 narasumber (Ketua RW lokasi terpilih) yang memberikan nilai skor 3 pada penilaian kondisi jalan. Hal ini dikarenakan tingkat kerusakan jalan di lokasi terpilih $<50.00 \%$.

\subsection{Saluran Drainase}

Pada ketiga lokasi yaitu RW 02 (Kelurahan Pekayon), RW 01 (Kelurahan Tanjung Barat) dan RW 05 (Kelurahan Pejaten Timur), kondisi saluran drainase tergolong buruk (Gambar 14). Hal ini berdasarkan hasil penilaian 3 narasumber (Ketua RW lokasi terpilih) yang memberikan nilai skor 2 pada penilaian kondisi saluran drainase. Hal ini dikarenakan menurut narasumber, ketinggian air di saluran drainase pada lokasi terpilih relatif tinggi yaitu $\leq 50.00 \%$. Selain itu diketahui bahwa saluran drainase berbentuk saluran terbuka dengan kedalaman berkisar antara $10-25 \mathrm{~cm}$ dan lebar berkisar antara 10 - $30 \mathrm{~cm}$. Kondisi saluran drainase yang buruk disebabkan kedalaman saluran air yang relatif dangkal sehingga tidak mampu menampung air limbah rumah tangga masyarakat sekitar. Selain itu juga disebabkan tumpukan sampah yang tergenang dan mengendap pada saluran drainase menyebabkan rendahnya tingginya genangan air. Hal ini perlu diperhatikan karena beresiko menyebabkan banjir di kawasan tersebut. Oleh karena itu perlu adanya revitalisasi saluran drainase, guna mencegah terjadinya banjir di kawasan tersebut. Hal yang dapat dilakukan yaitu perbaikan sistem drainase dengan pendekatan Sustainable Urban Drainage System (SUDS). Menurut Dinas PU, Sustainable Urban Drainage System (SUDS) atau sistem drainase berkelanjutan adalah teknik pengelolaan air 
yang berfokus pada pengendalian aliran air permukaan dengan prinsip menampung dan meresapkan air. Adapun cara kerjanya yaitu, air hujan yang jatuh ditahan melalui bangunan resapan, baik buatan maupun alamiah seperti kolam tandon, sumur-sumur resapan, biopori, dan lainnya, untuk selanjutnya diresapkan ke dalam tanah. Oleh karena itu perlu adanya peran serta masyarakat dalam penerapan Sustainable Urban Drainage System (SUDS).

\subsection{Air Bersih}

Air bersih merupakan salah satu kelengkapan dasar fisik dalam suatu permukiman dan memegang peranan penting dalam kehidupan manusia. Pada ketiga lokasi terpilih yaitu RW 02 (Kelurahan Pekayon), RW 01 (Kelurahan Tanjung Barat) dan RW 05 (Kelurahan Pejaten Timur) pelayanan air bersih tergolong baik. Hal ini berdasarkan hasil penilaian 3 narasumber (Ketua RW lokasi terpilih) yang memberikan nilai skor 3 pada penilaian pelayanan air bersih. Menurut narasumber pelayanan air bersih pada permukiman tidak terencana di lokasi terpilih tergolong dalam kondisi yang baik. Hal ini dikarenakan menurut narasumber hampir seluruh unit rumah sudah mendapatkan pelayanan air bersih (90 \%) yang berasal dari air tanah.

\subsection{Pembuangan Sampah}

Sarana pembuangan sampah juga merupakan salah satu kelengkapan dasar fisik permukiman. Pada ketiga lokasi terpilih yaitu RW 02 (Kelurahan Pekayon), RW 01 (Kelurahan Tanjung Barat) dan RW 05 (Kelurahan Pejaten Timur) pelayanan pembuangan sampah tergolong baik (Gambar 15). Hal ini berdasarkan hasil penilaian 3 narasumber (Ketua RW lokasi terpilih) yang memberikan nilai skor 3 pada penilaian pelayanan pembuangan sampah. Hal ini dikarenakan menurut narasumber sebagian besar masyarakat $(>80 \%)$ sudah mendapatkan pelayanan pembuangan sampah. Selain itu juga dikarenakan frekuensi pengangkutan sampah dilakukan setiap hari. Pelayanan pembuangan sampah di lokasi terpilih ditangani oleh Suku Dinas Kebersihan setempat. Selain itu berdasarkan hasil turun lapang diketahui bahwa terdapat sarana pengelolaan sampah berupa Tempat Penampuangan Sampah Sementara (TPS), di RW 01 Kelurahan Tanjung Barat dan RW 05 Kelurahan Pejaten Timur. Sarana pengangkutan sampah berupa gerobak sampah berkapasitas volume sampah $\pm 1 \mathrm{~m} 3$.
Mekanisme pengangkutan sampah di kawasan permukiman tidak terencana di lokasi terpilih dilakukan dengan cara diangkut oleh petugas kebersihan, kemudian dikumpulkan di TPS untuk selanjutnya di buang ke TPA (Tempat Pembuangan Akhir) Bantar Gebang.

\section{Karakteristik Permukiman Terencana}

\section{Pola permukiman}

Berdasarkan hasil analisis pola permukiman dengan menggunakan software Google Earth diketahui bahwa pada permukiman terencana di lokasi terpilih memiliki pola permukiman yang berbeda. Pada Komplek Tanjung Mas Estate (TME) memiliki pola konvensional. Pada Komplek Batu Permata memilki pola cluster. Bangunan rumah pada umumnya berorientasi pada jalan dan sebagian besar bangunan rumah merupakan bangunan permanen.

Pola permukiman pada permukiman terencana di lokasi terpilih memiliki pola permukiman konvensional dan cluster. Pada Komplek TME memiliki pola permukiman berbentuk konvensional. Hal ini dikarenakan komplek TME berdiri Tahun 1983, dan pada saat itu konsep konvensional tersebut merupakan konsep perencanaan permukiman terencana yang pertama dikenal dan berkembang pada Tahun 1970-1990. Dengan demikian diketahui bahwa faktor keterbatasan konsep perencanaan perumahan mempengaruhi pola permukiman di Komplek TME . Sedangkan pada Komplek Batu Permata memilki pola permukiman cluster. Pada konsep cluster rumah dibangun secara berkelompok untuk mendapatkan kepadatan yang tinggi. Hal ini dikarenakan keterbatasan lahan yang dimiliki komplek Batu Permata yaitu sebesar $5950 \mathrm{~m} 2$, sehingga rumah-rumah dibangun secara berkelompok guna mendapatkan tingkat kepadatan bangunan yang tinggi. Hal ini terlihat dari jumlah unit bangunan di komplek Batu Permata yang hanya berjumlah 22 unit. Dengan demikian diketahui bahwa faktor luas lahan mempengaruhi pola permukiman di Komplek Batu Permata.

\section{Ukuran permukiman}

Berdasarkan hasil hasil wawancara dengan Ketua RT setempat diketahui bahwa pada Komplek TME tergolong ke dalam permukiman berukuran sedang. Hal ini dikarenakan komplek tersebut memiliki jumlah penduduk sebesar 1719 jiwa. Sedangkan pada Komplek 
Batu Permata tergolong ke dalam permukiman berukuran kecil. Hal ini dikarenakan komplek tersebut memiliki jumlah penduduk sebesar 96 jiwa.

Permukiman terencana di lokasi terpilih dapat dikategorikan sebagai permukiman kecil dan sedang. Pada Komplek TME tergolong ke dalam permukiman ukuran sedang. Kawasan perumahan ini dihuni sekitar 1719 jiwa yang terdiri dari $480 \mathrm{KK}$. Hal ini disebabkan kawasan Komplek Tanjung Mas Estate tergolong sebagai wisma besar. Hal ini dapat dilihat berdasarkan luas kavling rata-rata $>400 \mathrm{~m} 2$. Kawasan Komplek TME yang tergolong sebagai wisma besar, menyebabkan tingginya harga lahan dan unit rumah di kawasan tersebut dan berdampak pada jumlah penduduk di dalamnya. Sedangkan Pada Komplek Batu Permata tergolong ke dalam permukiman ukuran kecil. Kawasan perumahan ini dihuni sekitar 96 jiwa yang terdiri dari $22 \mathrm{KK}$. Hal ini disebabkan kawasan Komplek Batu Permata tergolong sebagai wisma sedang. Hal ini dapat dilihat berdasarkan luas kavling rata-rata $>200 \mathrm{~m} 2$. Kawasan Komplek Batu Permata sebagai wisma sedang menyebabkan tingginya harga lahan dan unit rumah di kawasan tersebut dan berdampak pada jumlah penduduk di dalamnya. Selain itu juga disebabkan unit Tabel 5 Penilaian infrastruktur permukiman pada permukiman terencana

\begin{tabular}{lcccccc}
\hline Sampel pemukiman & \multicolumn{5}{c}{ Skor Aspek } & \\
\cline { 2 - 6 } & Jalan & Drainase & Air bersih & Sampah & Total & Keterangan \\
\hline Komplek Pekayon & 3 & 3 & 3 & 3 & 12 & Tinggi \\
Komplek BP & 3 & 3 & 3 & 3 & 12 & Tinggi
\end{tabular}

Keterangan: Nilai total 4-7 = Rendah, 8-10= Sedang, 11-12= Tinggi

(Sudah dijelaskan pada metode)

\subsection{Jalan}

Kondisi jalan pada lokasi terpilih (Komplek TME dan Komplek Batu Permata) tergolong ke dalam kondisi yang baik. Hal ini berdasarkan hasil penilaian 2 narasumber (Ketua RT lokasi terpilih) yang memberikan nilai skor 3 pada penilaian kondisi jalan. Hal ini dikarenakan tingkat kerusakan di lokasi terpilih $<50.00 \%$.

\subsection{Saluran Drainase}

Kondisi saluran drainase pada lokasi terpilih (Komplek TME dan Komplek Batu Permata) tergolong ke dalam kondisi yang baik. Hal ini berdasarkan hasil penilaian 2 narasumber (Ketua RT lokasi terpilih) yang memberikan rumah yang terbatas akibat keterbatasan luas Komplek Batu Permata.

\section{Kepadatan permukiman}

Berdasarkan hasil analisis kepadatan permukiman diketahui bahwa pada Komplek TME memiliki kepadatan rendah (30.95\%). Pada Komplek Batu Permata memiliki kepadatan sedang (45.75\%). Hal ini disebabkan peruntukkan kawasan ini yang termasuk ke dalam kawasan permukiman dengan Koefisien Dasar Bangunan (KDB) sedang-tinggi menurut RDTR Kecamatan Jagakarsa, sehingga menyebabkan tingkat kepadatan permukiman di kawasan ini masih tergolong rendah. Pada Komplek Batu Permata tergolong ke dalam permukiman kepadatan sedang. Hal ini disebabkan peruntukkan kawasan ini yang termasuk ke kawasan permukiman dengan KDB sedang-tinggi menurut RDTR Kecamatan Pasar Minggu, sehingga menyebabkan tingkat kepadatan permukiman di kawasan ini masih tergolong sedang.

\section{Infrastruktur permukiman}

Berdasarkan hasil analisis diketahui bahwa kondisi infrastruktur di ketiga lokasi terpilih tergolong baik. Hal ini dapat dilihat berdasarkan nilai total seluruh aspek (Tabel 5). 
No. 23 Tahun 2006 tentang petunjuk teknis kawasan siap bangun dan lingkungan siap bangun berdiri sendiri.

\subsection{Air Bersih}

Kondisi pelayanan air bersih pada lokasi terpilih (Komplek TME dan Komplek Batu Permata) tergolong baik. Hal ini berdasarkan hasil penilaian 2 narasumber (Ketua RT lokasi terpilih) yang memberikan nilai skor 3 pada penilaian pelayanan air bersih. Hal ini dikarenakan menurut narasumber seluruh unit rumah sudah mendapatkan pelayanan air bersih (100 \%), yang berasal dari air tanah.

\subsection{Pembuangan Sampah}

Kondisi pelayanan sampah di lokasi terpilih (Komplek TME dan Komplek Batu Permata) tergolong baik. Hal ini berdasarkan hasil penilaian 2 narasumber (Ketua RT lokasi terpilih) yang memberikan nilai skor 3 pada penilaian pelayanan pembuangan sampah. Hal ini dikarenakan menurut narasumber seluruh penghuni perumahan sudah mendapatkan pelayanan pembuangan sampah (100.00\%). Selain itu juga dikarenakan frekuensi pengangkutan sampah dilakukan setiap hari (Komplek Batu Permata) dan setiap 2 hari sekali (Komplek Tanjung Mas Estate). Sarana pengangkutan sampah berupa gerobak sampah berkapasitas volume sampah $\pm 1 \mathrm{~m}$. Mekanisme pengangkutan sampah pada lokasi terpilih dengan cara diangkut oleh petugas kebersihan, kemudian dikumpulkan di TPS terdekat untuk selanjutnya di buang ke TPA (Tempat Pembuangan Akhir) Bantar Gebang.

\section{Rekomendasi Pengelolaan}

Berdasarkan hasil kajian ini, diberikan rekomendasi untuk pengelolaan permukiman di DAS Ciliwung Hilir:

1. Perubahan lahan dari RTH menjadi ruang terbangun pada periode 1993-2013 sebesar $70.07 \%$ terutama terjadi di Kecamatan Pasar Rebo, Jagakarsa dan Pasar Minggu yang juga diketahui memiliki laju pertambahan penduduk yang relatif tinggi dibandingkan kecamatan lain. Dengan demikian perlu adanya pengendalian perubahan $\mathrm{RTH}$ menjadi ruang terbangun baik oleh pemerintah maupun oleh masyarakat melalui pendekatan teknis seperti mengutamakan pembangunan vertikal dan menambahkan vegetasi melalui pembangunan roof garden dan vertical greenery di kawasan permukiman.

2. Permukiman di lokasi sampel di dominasi oleh permukiman tidak terencana $(87.23 \%)$. Hal ini disebabkan semakin bertambahnya jumlah penduduk sehingga mendorong peningkatan kebutuhan lahan untuk dijadikan permukiman. Oleh karena itu perlu adanya pengendalian laju penambahan permukiman tidak terencana oleh pemerintah melalui mekanisme perizinan yang tegas dan konsisten.

3. Pada permukiman tidak terencana di lokasi sampel memiliki karakteristik permukiman berupa kepadatan permukiman rendah-sedang. Hal ini sejalan dengan Rencana Detail Tata Ruang (RDTR) Kecamatan Pasar Rebo, Jagakarsa dan Pasar Minggu sebagai kawasan permukiman dengan KDB sedangtinggi. Kondisi ini perlu dipertahankan dengan cara mengontrol pemberian izin pembangunan permukiman (IMB).

4. Pada permukiman tidak terencana di lokasi terpilih, memiliki karakteristik berupa buruknya infrastruktur permukiman yaitu drainase permukiman. Hal ini disebabkan oleh rendahnya kapasitas saluran drainase sehingga berpotensi menyebabkan banjir di wilayah tersebut. Dengan demikian perlu adanya revitalisasi saluran drainase melalui pendekatan Sustainable Urban Drainage System (SUDS) atau sistem drainase berkelanjutan, yaitu teknik pengelolaan air yang berfokus pada pengendalian aliran air permukaan dengan prinsip menampung air pada bangunan serapan (kolam tandon, sumur resapan, lubang biopori) untuk selanjutnya di resapkan ke dalam tanah.

\section{SIMPULAN DAN SARAN}

\section{Simpulan}

Berdasarkan hasil analisis peta perubahan lahan di DAS Ciliwung Hilir periode 1993-2013, diketahui bahwa perubahan penutupan lahan terbesar terjadi pada RTH menjadi ruang terbangun sebesar $70.07 \%$. Perubahan lahan disebabkan oleh faktor-faktor diantaranya pertambahan jumlah penduduk dan peruntukkan wilayah untuk permukiman berdasarkan Rencana Tata Ruang Wilayah (RTWR). Permukiman di DAS Ciliwung Hilir terdiri dari permukiman tidak terencana $(87.23 \%)$ dan permukiman terencana (12.77\%). Karakteristik permukiman tidak terencana di 
DAS Ciliwung Hilir adalah memiliki pola permukiman linier (memanjang), ukuran permukiman sangat besar, kepadatan permukiman rendah-sedang, serta kondisi infrastruktur permukiman baik. Karakteristik permukiman terencana di DAS Ciliwung Hilir adalah memiliki pola permukiman konvensional dan cluster, ukuran permukiman kecil-sedang, kepadatan permukiman rendahsedang, dan kondisi infrastruktur permukiman baik. Penelitian ini menghasilkan beberapa rekomendasi yaitu pengendalian perubahan RTH, meningkatkan luas RTH melalui pembangunan roof garden atau vertical greenery di kawasan permukiman, pengendalian penambahan permukiman tidak terencana oleh pemerintah mekanisme perizinan yang tegas dan konsisten, mempertahankan RDTR yang ada, khususnya rencana detail kawasan permukiman, dan revitalisasi saluran drainase melalui pendekatan sistem drainase berkelanjutan.

\section{Saran}

Dalam menganalisis perubahan penutupan lahan di DAS Ciliwung Hilir, diperlukan penambahan sampel wilayah lainnya, guna mengetahui faktor-faktor lain penyebab perubahan lahan di wilayah tersebut. Dalam mengelola kawasan permukiman di wilayah DAS perlu adanya studi lanjutan terkait karakteristik sosial masyarakat dan sarana prasarana yang lebih mendalam.

\section{DAFTAR PUSTAKA}

Alvino. 2014. Rencana Revitalisasi Kota Tuo Sawahlunto Provinsi Sumatera Barat. [skripsi]. Bogor (ID): Institut Pertanian Bogor.

Aryanti M. 2011. Monitoring Perubahan Penutupan Lahan dengan Menggunakan Sistem Informasi Geografi (SIG) dan Penginderaan Jauh. (Studi Kasus: Kawasan Puncak, Kabupaten Bogor, Jawa Barat. [skripsi]. Bogor (ID): Institut Pertanian Bogor.

[BPS] Badan Pusat Statistik. 1994. Jakarta Dalam Angka. Jakarta (ID):BPS. [BPS] Badan Pusat Statistik. 2014. Jakarta Dalam Angka. Jakarta (ID):BPS. [BSN] Badan Standardisasi Nasional. 2003. Persyaratan Umum Sistem Jaringan dan Geometri Jalan Perumahan. Jakarta (ID):BSN.

Jaya, INS. 2010. Analisis Citra Digital, Perspektif Penginderaan Jauh untuk Pengelolaan Sumber
Daya Alam. Fakultas Kehutanan. Bogor (ID): Institut Pertanian Bogor.

[Kemendagri] Menteri Dalam Negeri Republik Indonesia. 1999. Keputusan Menteri Negara Perumahan dan Permukiman Nomor 9 tentang Pedoman Penyusunan Rencana Pembangunan dan Pengembangan Perumahan dan Permukiman di Daerah (RP4D). Jakarta (ID). Kemendagri.

[Kemenhut] Kementerian Kehutanan Republik Indonesia. 2009. Keputusan Menteri Kehutanan Republik Indonesia Nomor 328 tahun 2009 tentang Penetapan Daerah Aliran Sungai (DAS) Prioritas dalam Rangka Rencana Pembangunan Jangka Menengah (RPJM) tahun 2010-2014. Jakarta (ID): Kemenhut.

Kemenpera] Menteri Dalam Negeri Republik Indonesia. 2006. Keputusan Menteri Negara Perumahan Rakyat Nomor 32 tentang Petunjuk Teknis Kawasan Siap Bangun dan Lingkungan Siap Bangun yang Berdiri Sendiri. Jakarta (ID). Kemenpera.

[Kemen PU] Kementrian Pekerjaan Umum Republik Indonesia. 2005. Pedoman teknis tata cara pemilihan lokasi prioritas untuk pengembangan perumahan dan permukiman di kawasan perkotaan. Jakarta (ID). Kemen PU.

[Kemen PU] Kementrian Pekerjaan Umum Republik Indonesia. Sistem Informasi Kawasan Kumuh Perkotaan. .[Internet] Diakses pada April 2014. Tersedia dalam http://ciptakarya.pu.go.id.

Masykur. 2006. Karakteristik Permukiman Dualistik dan Tingkat Keberhasilan Penghunian di Bogor (Studi Kasus di Kota Bogor, Jawa Barat). [Tesis]. Bogor (ID): Institut Pertanian Bogor.

Melati FF, Hendrawan D, and Sitawati A. (2002). Land use and water quality relationships in the Ciliwung river basin, Indonesia. Jakarta (ID): Trisakti University.

Mulyana R, Alikodra HS, Arifin HS, Prasetyo LB. 2007. Karakteristik Bangunan Rumah dan Bentuk Permukiman di Wilayah DAS Cianjur, Jawa Barat. J STNI Volume 17(3):217.

Mursitaningsih. 2009. Analisis Kinerja Saluran Drainase di Darah Tangkapan Air Hujan Sepanjang Kali Pepe Kota Surakarta [skripsi]. Surakarta (ID): Universitas Sebelas Maret. 
Pemerintah Republik Indonesia. 1992. UndangUndang Republik Indonesia Nomor 4 Tahun 1992 tentang Perumahan dan Permukiman. Jakarta (ID). Sekretariat Negara

Riastika M. 2011. Pengelolaan Air tanah Berbasis Konservasi di Recharge Area Boyolali (Studi Kasus Recharge Area Cepogo, Boyolali, Jawa Tengah. JIL Volume 9(2):86-97.

Syartinilia. 2001. Studi Karakteristik Permukiman di DAS Ciliwung Tengah [skripsi]. Bogor (ID): Institut Pertanian Bogor.

Syartinilia. 2004. Penerapan Multi Criteria Decision Making (MCDM) dan Geographical Information System (GIS) pada Evaluasi Peruntukan Lahan (Studi Kasus: DAS Ciliwung Hulu, Kabupaten Bogor, Jawa Barat) [tesis]. Bogor (ID): Institut Pertanian Bogor.

Wahyuni S. 2014. Studi Nilai dan Distribusi Biodiversitas di Daerah Aliran Sungai (DAS) Ciliwung Hulu. [skripsi]. Bogor (ID): Institut Pertanian Bogor. 